\title{
Appraisal of Different Inorganic Inhibitors Action on the Corrosion Control Mechanism of Mild Steel in $\mathrm{HNO}_{3}$ Solution
}

\author{
Prakash Magrati', Dhruba Babu Subedi², Durga Bhakta Pokharel' ${ }^{2}$, Jagadeesh Bhattarai*3 \\ ${ }^{I}$ Department of Chemistry, Tri-Chandra M. Campus, Tribhuvan University, Kathmandu, Nepal \\ ${ }^{2}$ Envirnmental Corrosion Centre, Institute of Metal Research, Chinese Academy of Sciences, Shenyang, China \\ ${ }^{3}$ Central Department of Chemistry, Institute of Science \& Technology, Tribhuvan University, Kirtipur, Nepal \\ *Corresponding E-mail: bhattarai_05@yahoomail.com \\ (Received: April 2, 2020; Revised: June 8, 2020 \& Accepted: June 22, 2020)
}

\begin{abstract}
Effects of eco-friendly inorganic inhibitors (i.e., calcium nitrate, zinc sulfate, sodium hexametaphosphate and sodium tetra-borate or borax) for the mild steel corrosion control in $1 \mathrm{M} \mathrm{HNO}_{3}$ solution open to air at $28 \pm 1$ ${ }^{\circ} \mathrm{C}$ were studied using corrosion, inhibition efficiency, and corrosion potential tests. The corrosion rate of the mild steel is increased with increasing the concentrations of $\mathrm{HNO}_{3}$ solution from $0.01 \mathrm{M}$ to $1 \mathrm{M}$. The uses of 200-2400 ppm of these inhibitors enhanced the corrosion resistance properties of the mild steel in $1 \mathrm{M}$ $\mathrm{HNO}_{3}$ solution. The corrosion resistance property of the mild steel is generally decreased with increasing the concentration of all corrosion inhibitors used here. The most efficient corrosion inhibitor is found to be calcium nitrate and it is followed by zinc sulfate, sodium hexametaphosphate, and borax subsequently. Adsorption of these inorganic salts inhibitors on the mild steel surface obeyed Langmuir adsorption isotherm. Consequently, the corrosion inhibition mechanism of the four inorganic salts for the mild steel corrosion control can be explained based on the formation of the passive film. It is found from the corrosion potential measurement that the cathodic type of corrosion inhibition action was by calcium nitrate, whereas zinc sulfate, sodium hexametaphosphate, and borax are acted as a mixed type of the inhibitors in $1 \mathrm{M} \mathrm{HNO}_{3}$ solution. In summary, all four inorganic inhibitors utilized in the present study can be applied as an environmentally friendly inhibitor to control the corrosion of the mild steel in aggressive $\mathrm{HNO}_{3}$ solutions.
\end{abstract}

Keywords: Corrosion inhibitor, inorganic salts, mild steel, nitric acid, immersion tests

\section{Introduction}

Different types of iron and iron-containing alloys (for example, steels) are world-widely used as structural materials. Material scientists, technologists, and chemical engineers are facing a problem of the untimely degradation of such structural materials due to the unwanted and unavoidable corrosion processes, mainly in slightly basic, neutral or acidic solutions [1]. The iron and steels are generally passive at a $\mathrm{pH}$ higher than 9.6, even though the passivity decreases in very strong alkaline solutions (i.e., $>13.5 \mathrm{pH}$ ) where it tends to dissolve to form a highly corrosive product of hypo-ferrite $\left(\mathrm{HFeO}^{2-}\right)$ in aqueous solution [2].
Hence, the uses of different corrosion control approaches are becoming an important subject in the field of different types of unwanted destruction/ damages of such structural materials mainly in aggressive acidic solutions. Corrosionists need to understand what can be done to reduce such type of corrosion problems of the structural materials like mild steel in various acidic environments to ensure its durability for long periods although corrosion prevention techniques were constantly reviewed and discussed by various research groups in the past [3-6]. In particular, nitric acid is used as pickling solution to remove rust formed on the surface of different types of steels and iron. On the other hand, the passivation 
of numerous steel-made structures and equipment is generally practiced in nitric acid by the USA DoD (Department of Defense) and NASA (National Aeronautics and Space Administration) [7].

In this context, it became a fundamental research concern of corrosion scientists, engineers, and technologists to control the corrosion of such metallic materials in aggressive acidic electrolytes using eco-friendly corrosion inhibitors. It is purposeful to highlight the corrosion inhibitor (CI) which is a chemical substance that when added in a very small concentration to an aggressive electrolyte like nitric acid, effectively controls the corrosion damages of the metallic materials in the corrosive media [8].

The highly toxic nature of the widely used chromiumcontaining organic and inorganic corrosion inhibitors (CIs) in the early stage has motivated now to look the eco-friendly corrosion inhibitors $[9,10]$, because such CIs are quite toxic with their direct impacts on human health, and do not fulfill completely the requirements imposed by the environmental protection standards. Therefore, nowadays, the corrosion control method of metallic materials using various eco-friendly CIs to prevent metallic corrosion is becoming a fundamental research concern of corrosionists, and chemical engineers [11-19], because the eco-friendly corrosion inhibitors generally impose zero or negligible toxicity to the environment and human beings.

In general, the eco-friendly inhibitors restrict the rate of anodic or/and cathodic reactions involved in the corrosion damages by blocking active sites of the corroded metal/alloy surfaces. On the other hand, the corrosion inhibition mechanism occurs through the adsorption of the inhibitors ions/molecules on the corroding metal/alloy surfaces to form more stable films. Past researches had reported that some organic [20-25] and inorganic [26-30] compounds were used as eco-friendly corrosion inhibitors because they form complexes with metal ions on metal/alloy surface. Investigations of corrosion-inhibiting ability of inorganic radicals or ions, e.g., nitrites, molybdates, tungstates, polyphosphates are now being increasingly used as eco-friendly inhibitor due to their zero-toxic nature [10,31-36]. It was reported that calcium nitrate acted as retarder against chloride-induced concrete structures like well-known corrosion inhibitor of calcium nitrite [37] because it is also cheaper, less harmful and more available [38]. Similarly, sodium polyphosphate, zinc sulfate, borate etc. are widely used as the corrosion controller for different metals and alloys mostly in chloride containing neutral solutions [39-41], although these inorganic salts are rarely used as corrosion retarder in acidic media.

Extensive research has led to the discovery of a new class of corrosion inhibitors that are eco-friendly. Previous studies were reported about the corrosion behavior of different ferrous structural materials used in Nepal in different corrosive environments [42-51], although a few studies were focused on the effects of eco-friendly plant-extracted green inhibitors on the mild steel corrosion $[14,15,18]$. In this context, the present work was aimed to study the effects of four inorganic compounds; $\mathrm{Ca}\left(\mathrm{NO}_{3}\right)_{2}, \mathrm{ZnSO}_{4},\left(\mathrm{NaPO}_{3}\right)_{6}$ and $\mathrm{Na}_{2}\left[\mathrm{~B}_{4} \mathrm{O}_{5}(\mathrm{OH})_{4}\right] \cdot 8 \mathrm{H}_{2} \mathrm{O}$ as eco-friendly inhibitors for the mild steel corrosion prevention in $1 \mathrm{M} \mathrm{HNO}_{3}$ solution open to air at $28 \pm 1{ }^{\circ} \mathrm{C}$ using immersion tests, inhibition efficiency, and corrosion potential measurements.

\section{Materials and Methods}

\section{Preparation of mild-steel coupon}

The mild steel coupons having a dimension of (2 $\mathrm{cm} \times 3 \mathrm{~cm} \times 0.5 \mathrm{~cm}$ ) were used for both corrosion inhibition and electrochemical tests. The approximate chemical constituents of the mild steel coupons were reported as in wt. (\%); $\mathrm{C}=0.17, \mathrm{P}=0.05, \mathrm{Si}=0.04$, $\mathrm{Mn}=0.90, \mathrm{~S}=0.05$ and balanced by iron as described elsewhere $[15,16]$. The surface of each sample coupon was mechanically polished with different grades (200-1500 grit) SiC paper using ethanol, rinsed with acetone, and dried by air blowing until the surface exhibited mirror-like reflection to obtain reproducible results from the corrosion as well as the electrochemical tests.

\section{Corrosion test}

The corrosion test of the mild steel coupons was carried out after immersion for 240 hours in $1 \mathrm{M}$ $\mathrm{HNO}_{3}$ solution open to air at $28 \pm 1{ }^{\circ} \mathrm{C}$ in absence and presence of different concentrations (i.e., 200, 400, $800,1200,1600 \& 2400 \mathrm{ppm}$ ) of calcium nitrate, zinc sulfate, sodium hexametaphosphate and borax as ecofriendly corrosion inhibitors. Besides, comparative 
studies on the corrosion tests of the mild steel coupons in different concentrations of nitric and hydrochloric acids were also estimated. Weight-loss method was used to estimate the average corrosion rate of the mild steel coupons using the equation 1 [52].

$$
\text { Corrosion Rate }\left(\mathrm{mm} \cdot \mathrm{y}^{-1}\right)=\frac{87600 \times \Delta w}{d \times A \times t}
$$

Where, $\Delta \mathrm{w}$ is the weight loss of the mild steel sample in gram $(\mathrm{g}), \mathrm{d}$ is the density of the steel sample $(=8.76$ in $\mathrm{g} / \mathrm{cm}^{3}, \mathrm{~A}$ is the area of the sample in $\mathrm{cm}^{2}, \mathrm{t}$ is the immersion time in hour, and 87600 is the conversion factor as described elsewhere [2].

\section{Inhibition efficiency test}

The inhibition efficiency $\left(\mathrm{IE}_{\mathrm{CR}}\right)$ and the degree of surface coverage $(\theta)$ of the inhibitor molecule adsorbed on the mild steel surface in $1 \mathrm{M} \mathrm{HNO}_{3}$ solution open to air at $28 \pm 1{ }^{\circ} \mathrm{C}$ were estimated using following equations 2 and 3 [53,54], respectively, where, $\mathrm{CR}_{\text {(unhib.) }}$ and $\mathrm{CR}_{\text {(inhib.) }}$ are the corrosion rates in absence and presence of the corrosion inhibitors of calcium nitrate, zinc sulfate, sodium hexametaphosphate, and borax, respectively. It is meaningful for citing here that all the calculations of the surface coverage $(\theta)$ from the corrosion data are based on the assumption that the presently used inhibitors totally prevent the mild steel dissolution from the covered surfaces of it [55].

$$
\begin{aligned}
& I \mathrm{E}_{\mathrm{CR}}(\%)=\frac{C R_{(\text {unhib.) }} C R_{(\text {inhib.) }}}{C R_{(\text {unhibit. })}} \times 100 \\
& \theta=\frac{C R_{(\text {unhib.) }} C R_{(\text {inhib.) }}}{C R_{(\text {unhib.) }}}
\end{aligned}
$$

The corrosion inhibition mechanism was studied using the Langmuir adsorption model [56] which is expressed in equation 4 .

$$
\frac{C}{\theta}=\left(\frac{1}{K_{a d s}}\right)+\mathrm{C}
$$

Where, $\mathrm{C}$ is the inhibitor concentration and $\mathrm{K}_{\text {ads }}$ is the adsorptive equilibrium which is estimated from the intercept of a straight line obtained by plotting $\mathrm{C} / \theta \mathrm{vs}$ C. The $\mathrm{K}_{\mathrm{ads}}$ value was used to estimate the standard free energy of adsorption $\left(\Delta \mathrm{G}^{\circ}{ }_{\text {ads }}\right)$ using equation 5 [57].

$$
\Delta G_{a d s}^{o}=-\mathrm{RT} \ln \left(55.5 \times K_{a d s}\right)
$$

Where $\mathrm{R}$ is gas constant, $\mathrm{T}$ is the temperature in Kelvin and the value of 55.5 is the molar concentration of water in solution.

\section{Corrosion potential measurement}

For understanding the effect of these four ecofriendly inorganic salts on the corrosion inhibition behavior for the mild steel coupons, the corrosion potential of the steel coupons was measured using a two-electrode system potentiometer (Osawa Digital Potentiometer) in $1 \mathrm{M} \mathrm{HNO}_{3}$ solution open to air at $28 \pm 1{ }^{\circ} \mathrm{C}$ in absence and presence of different concentrations (i.e., 200, 400, 800, 1200, 1600 \& $2400 \mathrm{ppm}$ ) of calcium nitrate, zinc sulfate, sodium hexametaphosphate, and borax. A saturated calomel electrode (SCE) and the mild steel sheet were used as reference and working electrodes, respectively. The mechanically polished test coupons were clipped by a sample holder that was made by welding the crocodile pin with a titanium rod. The readings of the corrosion potential were taken immediately after immersion of the coupon in the electrolytic solution until 24 hours at different time intervals as described elsewhere [58]. A saturated calomel electrode (SCE) and the steel coupons were used as the reference and working electrodes, respectively.

\section{Results and Discussion}

\section{Corrosion rate in acid solutions}

Figure 1 shows the corrosion rates of the mild steel coupons after their immersion for 240 hours in 0.01

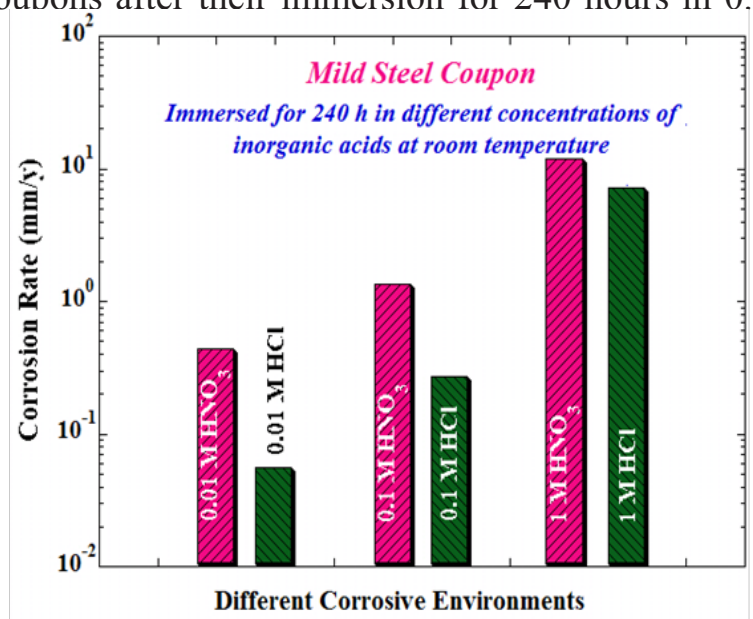

Figure 1: Corrosion rate of the mild steel in $\mathrm{HCl}$ and $\mathrm{HNO}_{3}$ concentrations open to air at $28 \pm 1{ }^{\circ} \mathrm{C}$ 
$\mathrm{M}, 0.1 \mathrm{M}$, and $1 \mathrm{M}$ solutions of hydrochloric and nitric acids at $28 \pm 1{ }^{\circ} \mathrm{C}$. The corrosion rate of the mild steel is found to be higher in all three concentrations of nitric acid than in hydrochloric acid. Consequently, it can be said that nitric acid seems to be more aggressive to the mild steel than that of hydrochloric acid having the concentration ranges from $0.01 \mathrm{M}$ to $1 \mathrm{M}$.

\section{Corrosion inhibition effect}

The corrosion rate of the mild steel coupons was decreased with increasing the concentrations of these four corrosion inhibitors, although it is nearly one order of magnitude lower in $2400 \mathrm{ppm}$ calcium nitrate addition than its absence in $1 \mathrm{M} \mathrm{HNO}_{3}$ as shown in Fig. 2. The effectiveness of the inhibition activity of the borax for the corrosion prevention of the mild steel in $1 \mathrm{M} \mathrm{HNO}_{3}$ solution is found to be less among the four eco-friendly inorganic corrosion inhibitors used herein. These results revealed that the use of these four corrosion inhibitors enhanced the corrosion resistance properties of the mild steel in 1 $\mathrm{M} \mathrm{HNO}_{3}$ solution open to air at $28 \pm 1{ }^{\circ} \mathrm{C}$.

\section{Inhibition efficiency and mechanism}

The inhibition efficiency of all four eco-friendly corrosion inhibitors as mentioned above is increased with increasing their concentrations as depicted in Figs. 3 and 4. The maximum inhibition efficiency for each corrosion inhibitor is observed at 1600-2400 ppm and the minimum is observed at $200 \mathrm{ppm}$ addition in $1 \mathrm{M} \mathrm{HNO}_{3}$ solution.

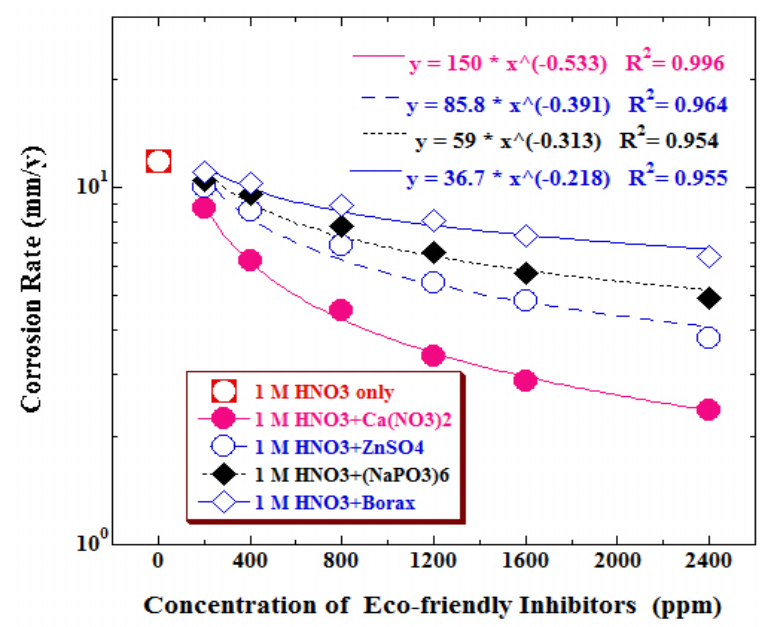

Figure 2: Changes in the corrosion rate of the mild steel $1 \mathrm{M} \mathrm{HNO}_{3}$ solution open to air at $28 \pm 1{ }^{\circ} \mathrm{C}$, as a function of four eco-friendly inhibitors concentration
Furthermore, it is observed that the most efficient corrosion inhibitor among these four inhibitors used here is found to be calcium nitrate with a maximum inhibition efficiency of about $80 \%$ at $2400 \mathrm{ppm}$ at $28 \pm 1{ }^{\circ} \mathrm{C}$ as shown in Fig. 3(a), whereas the borax is found to be the least efficient inhibitor with about $50 \%$ only in $1 \mathrm{M} \mathrm{HNO}_{3}$ solution with its $2400 \mathrm{ppm}$ addition at $28 \pm 1^{\circ} \mathrm{C}$ as shown in Fig. 4(b).
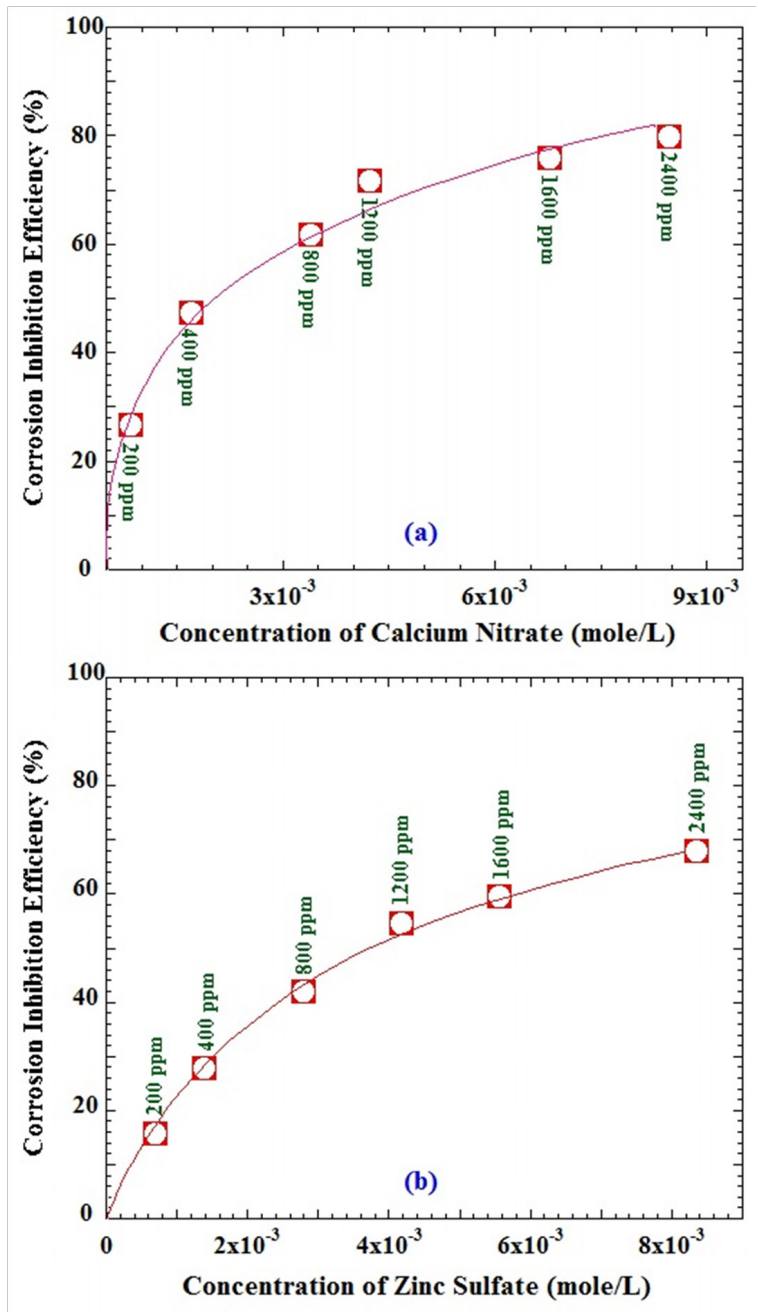

Figure 3: Changes in the corrosion inhibition efficiencies of (a) calcium nitrate and (b) zinc sulfate for the mild steel after its immersion for 240 hours in

$1 \mathrm{MHNO}_{3}$ solution open to air at $28 \pm 1{ }^{\circ} \mathrm{C}$

Likewise, the maximum corrosion inhibition efficiency of $2400 \mathrm{ppm}$ additions of the zinc sulfate and sodium hexametaphosphate in $1 \mathrm{M} \mathrm{HNO} 3$ was found about $60 \%$ for the corrosion control of the mild steel as depicted in Figs. 3(b) and 4(a). Consequently, it can be summarized that the order of the corrosion 
inhibition efficiencies of all four inorganic salts in one molar nitric acid solution at $28 \pm 1{ }^{\circ} \mathrm{C}$ for the mild steel is arranged as follows; $\mathrm{IE}_{\mathrm{Ca}(\mathrm{NO} 3) 2}>\mathrm{IE}_{\mathrm{ZnSO} 4} \geq \mathrm{IE}_{(\mathrm{NaPO}) 6}$ $>\mathrm{IE}_{\mathrm{Borax}}$. Therefore, it can be reasoned out from the above-observed results of the corrosion inhibition efficiency that these four inorganic salts can be used as eco-friendly corrosion inhibitors in $\mathrm{HNO}_{3}$ solutions for controlling of its corrosive nature towards the mild steel, and these results are in agreement with the results of corrosion resistance behavior as shown above in Figure 2.

Various adsorption isotherm models are applied for better understanding of such corrosion inhibition
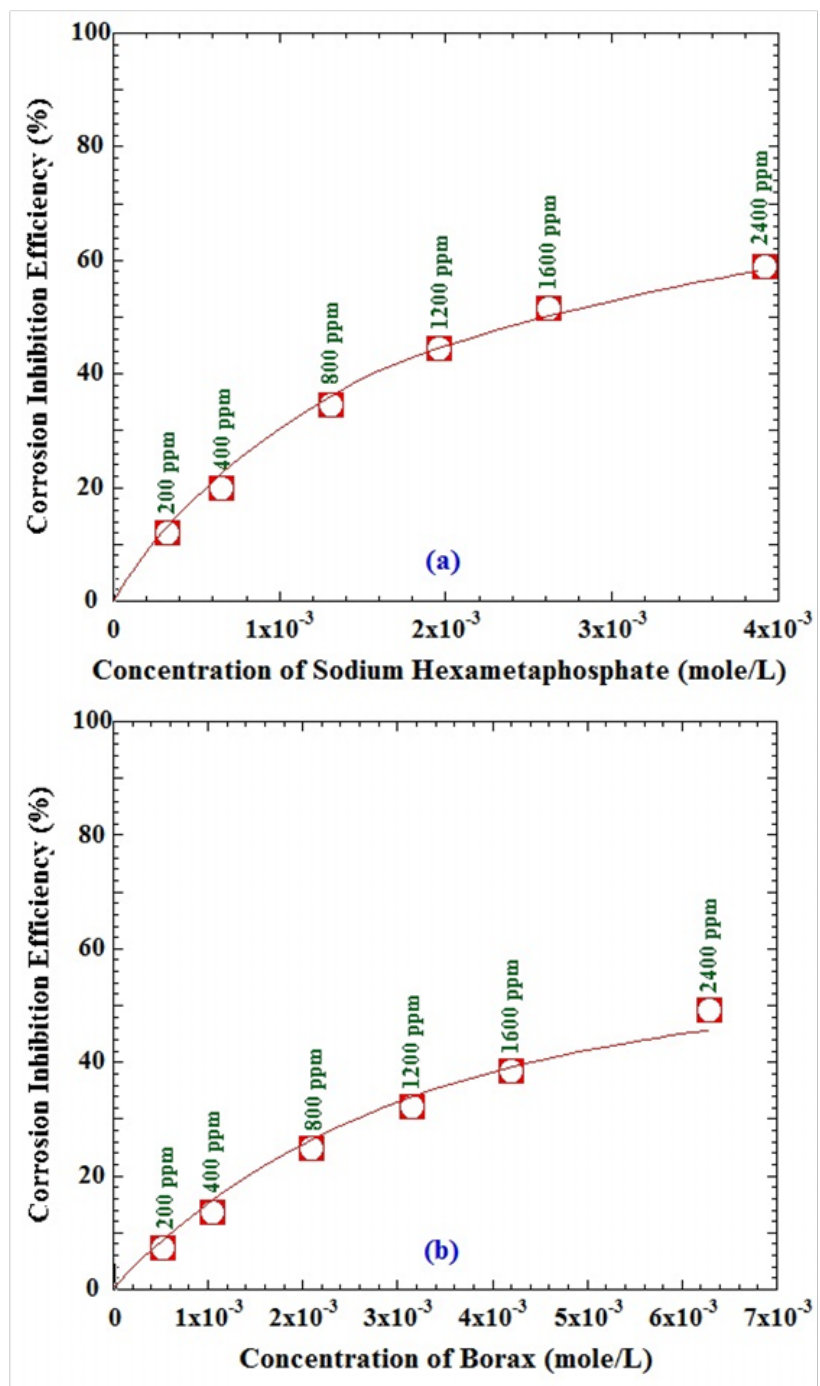

Figure 4: Changes in the inhibition efficiencies of (a) sodium hexametaphosphate and (b) borax for the mild steel after its immersion for 240 hours in $1 \mathrm{M}$ $\mathrm{HNO}_{3}$ solution open to air at $28 \pm 1^{\circ} \mathrm{C}$ mechanism by the additions of such eco-friendly inorganic compounds in aggressive electrolyte for metals/alloys. Langmuir adsorption isotherm is one of the simplest models and it describes the molecular interaction between the inhibitor molecules and the active surfaces of the corroded metallic materials based on the assumption that all adsorption sites are equivalent and the particle binding occurs independently from nearby sites being occupied or not $[56,59]$. It also shows the relationship between the ratio of inhibitor concentration to surface coverage $(\mathrm{C} / \theta)$ and the inhibitor concentration $(\mathrm{C})$ as described above in equation (4). To obtain the Langmuir adsorption plot to explain the inhibition mechanism, $\theta$ value was estimated from the calculated corrosion rate at different concentrations of all inhibitors used presently in $1 \mathrm{M} \mathrm{HNO}_{3}$ solution at $28 \pm 1^{\circ} \mathrm{C}$.

Figure 5 shows a linear relationship between $\mathrm{C} / \theta$ and $\mathrm{C}$ for the mild steel in $1 \mathrm{M} \mathrm{HNO}_{3}$ acid with the additions of different concentrations of all four types of eco-friendly inorganic inhibitors. The linear correlation coefficient $\left(\mathrm{R}^{2}\right)$ and slope of the straight line were used to choose the isotherm that best fit experimental data because it is almost equal to unity in all cases (Figure 5).

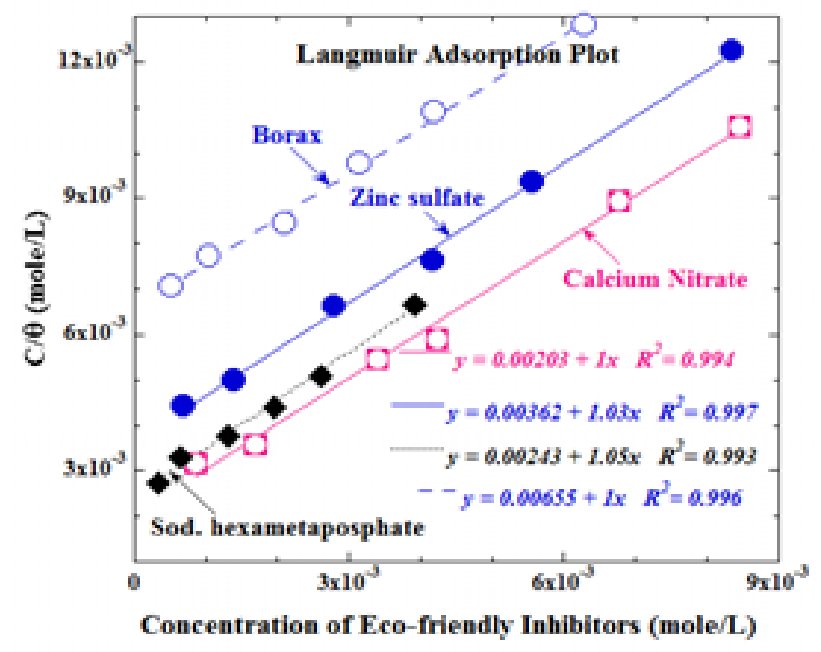

Figure 5: Langmuir adsorption plots for the mild steel in $1 \mathrm{M} \mathrm{HNO}_{3}$ solution in presence of different concentrations of four inorganic salts

These results indicated that the adsorption process obeyed the Langmuir adsorption isotherm to study the corrosion inhibition mechanism on the surface of the mild steel by the inhibitors of calcium nitrate, 
zinc sulfate, sodium hexametaphosphate, and borax in $1 \mathrm{M} \mathrm{HNO}_{3}$ at $28 \pm 1{ }^{\circ} \mathrm{C}$. Anions of these inorganic salts are thus adsorbed on the surfaces of the corroded mild steel which prevents their further corrosion by forming a barrier layer.

It was found that the $\Delta \mathrm{G}^{\circ}$ ads value for the use of calcium nitrate, zinc sulfate, sodium hexametaphosphate and borax as eco-friendly inhibitors in $1 \mathrm{M} \mathrm{HNO}_{3}$ solution at $28{ }^{\circ} \mathrm{C}$ for the corrosion control of the mild steel was found to be $-25.566,-24.118,-25.116$, and $-22.634 \mathrm{~kJ} / \mathrm{mole}$, respectively, which are consistent with the literature. Hence, authenticate physical adsorption of the inhibitors on the surface of the corroded mild surface by anions of the used four corrosion inhibitors. It is meaningful for mentioning here the fact that there is no interaction between the adsorbed corrosion inhibitor molecules, the energy of adsorption is independent of $\theta$, the metal/alloy surfaces contain a fixed number of adsorption sites and each site holds one adsorbed species according to the Langmuir isotherm model $[57,59]$.

The adsorptive equilibrium constant $\left(\mathrm{K}_{\text {ads }}\right)$ value was higher than 100 mole/g (i.e., between 153 and $493 \mathrm{~mole} / \mathrm{g}$ ) in the present work which attributes to stronger and more stable adsorbed layer formation on the metals or/and alloys surfaces [60]. It is reported that the $\Delta \mathrm{G}^{\circ}{ }_{\text {ads }}$ values of metals/alloys around $-25 \mathrm{~kJ} /$ mole or lower indicate adsorption of inhibitors onto metals/alloys surface with electrostatic interaction is due to physical adsorption, while those around or higher (more negative) than $-40 \mathrm{~kJ} /$ mole involve charge sharing between inhibitor molecules and metals/alloys surfaces are of chemisorption $[61,62]$.

Negative values of $\Delta \mathrm{G}^{\circ}$ ads ensure the spontaneity of the adsorption process and stability of the adsorbed layer of the corrosion inhibitors on the metals/alloys surfaces.

\section{Corrosion potential}

The corrosion potential measurement was carried out for a better understanding of the corrosion inhibition effect on the mild steel in $1 \mathrm{M} \mathrm{HNO}_{3}$ solution. Figure 6 shows the effects of calcium nitrate, zinc sulfate, sodium hexametaphosphate, and borax in the changes of the corrosion potential of the mild steel after
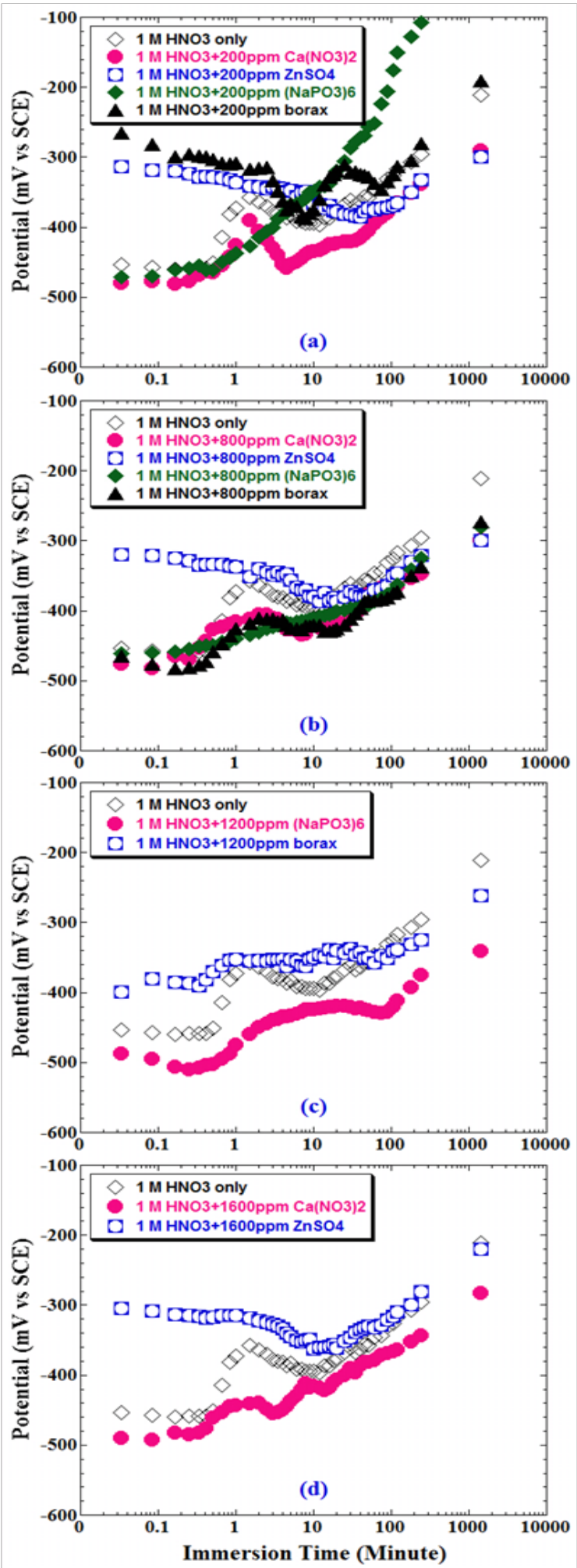

Figure 6: The potential changes for the steel coupons for 24 hours immersion in $1 \mathrm{M} \mathrm{HNO}_{3}$ solution open to air at $28 \pm 1{ }^{\circ} \mathrm{C}$ in absence and presence of (a) calcium nitrate, (b) zinc sulfate, (c) sodium hexametaphosphate, \& (d) borax 
immersion for 24 hours in $1 \mathrm{M} \mathrm{HNO}_{3}$ solution. It is clearly shown that the corrosion potential of mild steel in presence of calcium nitrate [Figure 6(a)] is generally shifted to more negative or less noble direction with increasing their concentrations than in $1 \mathrm{M} \mathrm{HNO}_{3}$ solution only.

However, its corrosion inhibition effect on the corrosion rate of the mild steel was found to be decreased with increasing concentrations as shown in Figure 2. Consequently, it can be said that calcium nitrate acts as the cathodic type of corrosion inhibitor.

There is no regular trend of corrosion potential change of the mild steel in $1 \mathrm{M} \mathrm{HNO}_{3}$ solution with the additions of zinc sulfate, sodium hexametaphosphate, and borax as depicted in Figures 6(b), 6(c) and 6(d), respectively. For example, the corrosion potential was reached to the maximum noble potential values of -81 $\mathrm{mV}$ vs SCE and $-121 \mathrm{mV}$ vs SCE when the additions of 200 and $400 \mathrm{ppm}$ of sodium hexametaphosphate, respectively, in $1 \mathrm{M} \mathrm{HNO}_{3}$ solution after immersion for 24 hours, although the corrosion potential is shifted to more negative direction with the additions of 800 and 1200 ppm than only in $1 \mathrm{M} \mathrm{HNO}_{3}$ solution as shown in Figure 6(c). These results indicated that zinc sulfate, sodium hexametaphosphate, and borax are acted as a mixed type of corrosion inhibitor based on corrosion potential measurements.

\section{Conclusions}

The effects of four eco-friendly inorganic corrosion inhibitors on electrochemical corrosion control of the mild steel in nitric acid solutions open to air at $28 \pm 1^{\circ} \mathrm{C}$ were studied using corrosion tests, inhibition efficiency, corrosion mechanism, and open circuit corrosion potential measurements. All the inorganic salts used to study present work are found to be an effective inhibitor to improve the corrosion resistance properties of the mild steel in $1 \mathrm{M} \mathrm{HNO}_{3}$. The maximum corrosion inhibition efficiencies of calcium nitrate, zinc sulfate, sodium hexametaphosphate and borax for the mild steel are found in order; $\mathrm{IE}_{\mathrm{Ca}(\mathrm{NO} 3) 2}=$ $80 \%>\mathrm{IE}_{\mathrm{ZnSO} 4} \geq \mathrm{IE}_{(\mathrm{NaPO}) 6}=60 \%>\mathrm{IE}_{\mathrm{Borax}}=50 \%$. The corrosion inhibition mechanism of these inorganic salts on the mild steel was explained by the Langmuir adsorption isotherm model. Experimentally obtained values of the standard free energy of adsorption
$\left(\Delta \mathrm{G}^{\circ}{ }_{\text {ads }}\right.$ ) of these eco-friendly inhibitors on the surface of the corroded mild steel found between about -22 and $-26 \mathrm{~kJ} / \mathrm{mol}$, suggested that adsorption of the corrosion inhibitors onto alloy surfaces is due to physical adsorption. The corrosion potential and corrosion rate results showed that the calcium nitrate acted as cathodic type inhibitor, while the zinc sulfate, sodium hexametaphosphate, and borax are of mixed type corrosion inhibitors to improve the corrosion resistance property of the mild steel in an aggressive electrolyte of $1 \mathrm{M} \mathrm{HNO}_{3}$ solution at ambient environment. The used inorganic salts can be used as an efficient and eco-friendly corrosion inhibitor so as to control the corrosion of iron-containing structural materials significantly in very corrosive acidic solutions at room temperature.

\section{Acknowledgement}

Department of Plant Resources, Thapathali, Kathmandu, is acknowledged for providing fivedigit microbalance facility to take weight loss of the samples.

\section{References}

1. R. W. Revie and H. H. Uhlig, Corrosion and Corrosion Control: An Introduction to Corrosion Science and Engineering, $4^{\text {th }}$ Ed., John Wiley and Sons, New York, 2008, pp. 490.

2. J. Bhattarai, Frontiers of Corrosion Science, $1^{\text {st }}$ Ed. Kshitiz Publisher, Kirtipur, Nepal, 2010, 1-297.

3. Q. Jiang, Q. Miao, W. Liang, F. Ying, F. Tong, Y. Xu, B. Ren, Z. Yao and P. Zhang, Corrosion behavior of arc sprayed $\mathrm{Al}-\mathrm{Zn}-\mathrm{Si}-\mathrm{RE}$ coatings on mild steel in $3.5 \mathrm{wt} \% \mathrm{NaCl}$ solution, Electrochimica Acta, 2014, 115, 644-656. (DOI: 10.1016/j.electacta.2013.09.156).

4. A. G. Marques and A. M. Simoes, EIS and SVET assessment of corrosion resistance of thin $\mathrm{Zn}-55 \%$ Al-rich primers: effect of immersion and controlled deformation, Electrochimica Acta, 2014, 148, 153-163. (DOI: 10.1016/j.electacta.2014.10.015).

5. FHWA-RD-01-156, Corrosion Costs and Preventive Strategies in the United States (eds. G. H. Koch, M. P. H. Brongers, N. G. Thompson, Y. P. Virmani, J. H. Payer), NACE International, Washington, USA, 2002, 1-11. (www. corrosioncost.com).

6. S. L. Chawla and R. K. Gupta, Materials Selection 
for Corrosion Control, ASM International, Materials Park, Ohio, USA, 1991.

7. P. L. Lewis, M. Kolody and J. Curran, Alternative to nitric acid for passivation of stainless steel alloys, In: NASA Technical Reports Server (NTRS), USA, 2013.

8. S. A. Bardford, Corrosion Control, $2^{\text {nd }}$ Ed. CASTI Publishing Inc., Alberta, Canada, 2001, 349-364.

9. M. W. Kendig and R. G. Buchheit, Corrosion inhibition of aluminum and aluminum alloys by soluble chromates, chromate coatings and chromate-free coatings, Corrosion, 2003, 9(5), 379-400. (DOI: 10.5006/1.3277570).

10.R. L. Twite and G. P. Bierwagen. Review of alternatives to chromate for corrosion protection of aluminum aerospace alloys, Progress in Organic Coatings, 1998, 33(2), 91-100. (DOI: 10.1016/ S0300-9440(98)00015-0).

11. C. G. Dariva and A. F. Galio, Corrosion inhibitorsprinciples, mechanisms and applications, In: Developments in Corrosion Protection (ed. M. Aliofkhazraei), INTECH open science, 2014, Chapter-16, pp. 365. (DOI: 10.5772/57255).

12. S. R. Tayler and B. D. Chambers, US Patent No. US2009/0000958A1, 2009, pp. 12. (https://www. google.com/patents/US20090000958).

13. B. N. Subedi, A. Amgain, S. Joshi and J. Bhattarai, Green approach to corrosion inhibition effect of Vitex negundo leaf extract on aluminum and copper metals in biodiesel and its blend, International Journal of Corrosion Scale and Inhibitors, 2019, 8(3), 744-759. (DOI: 10.17675/2305-6894-20198-3-21).

14.J. Bhattarai, M. Rana, M. R. Bhattarai and S. Joshi, Effect of green corrosion inhibitor of Callistemon plant extract on the corrosion behavior of mild steel in $\mathrm{NaCl}$ and $\mathrm{HCl}$ solutions, Proceedings of CORCON-2016, Sept 18-21, 2016, NACE/NIGIS, New Delhi, India, 2018, Paper No. MI-17, pp. 8. (https://www.researchgate.net/ publication/308604717).

15.M. Rana, S. Joshi and J. Bhattarai, Effect of different plants of Nepalese origin as green corrosion inhibitor for mild steel in $0.5 \mathrm{M} \mathrm{NaCl}$ solution, Asian Journal of Chemistry, 2017, 29(5), 1130-1134. (DOI:10.14233/ajchem.2017.20449).

16.B. Bards (ed.), Properties and Selection, Irons and Steels, In: Metal Handbook, ${ }^{\text {th }}$ Ed. American Society of Metals, 1978, vol. 1, pp. 185.

17. K. Amgain, B. N. Subedi, S. Joshi and J. Bhattarai,
Investigation on the effect of Tinospora cordifolia plant extract as a green corrosion inhibitor to aluminum and copper in biodiesel and its blend, Proceedings of CORCON 2018, Sept 30-Oct 3, 2018, NACE/NIGIS, Jaipur, India, 2018, Paper No. PP-19, pp. 11.

18. P. Katuwal, K. R. Gaire and J. Bhattarai, Study on the effects of ethylenediamine and plant extract as a corrosion inhibitor for mild steel passivation in bioethanol, Proceedings of CORCON 2018, Sept 30-Oct 3, 2018, NACE/NIGIS, Jaipur, India, 2018, Paper No. MCI-35, pp. 9.

19. S. Rajendran, R. Srinivasan, R. Dorothy, T. Umasankareswari and A. Al-Hashem, Green solution to corrosion problems- at a glance, International Journal of Corrosion Scale and Inhibitors, 2019, 8(3), 437-479. (DOI: 10.17675/2305-6894-2019-8-3-1).

20.E. S. Meresht, T. S. Farahani and J. Neshati, 2-butyne-1,4-diol as a novel corrosion inhibitor for APIx65 steel pipeline in carbonate/bicarbonate solution, Corrosion Science, 2012, 54, 36-44. (DOI: 10.1016/j.corsci.2011.08.052).

21. Q. B. Zhang and Y. Z. Hua, Corrosion inhibition of mild steel by alkyl imidazolium ionic liquids in hydrochloric acid, Electrochimica Acta, 2009 54, 1881-1887. (DOI: 10.1016/j. electacta.2008.10.025).

22.K. Bekkouch, A. Aouniti, B. Hammouti and S. Kertit, Substituted uracils on corrosion inhibitors for copper in $3 \% \mathrm{NaCl}$ solution, Corrosion Science, 2003, 45, 1619-1630. (DOI: 10.1016/ S0010-938X(02)00255-X).

23. M. Acharya, J. S. Chouhan, A. Dixit and D. K. Gupta, Green inhibitors for prevention of metal and alloys corrosion: an overview, Chemistry and Materials Research, 2013, 3(6), 16-24.

24. M. Dahmani, A. Et-Touhami, S. S. Al-Deyab, B. Hammouti and A. Bouyanzer, Corrosion inhibition of C38 steel in $1 \mathrm{M} \mathrm{HCl}$ : a comparative study of black pepper extract and its isolated piperine, International Journal of Electrochemical Science, 2010, 5, 1060-1069.

25. C. Verma, E. E. Ebenso and M. A. Quraishi, Alkaloids as green and environmental benign corrosion inhibitors: An overview, International Journal of Corrosion Scale and Inhibitors, 2019, 8(3), 512-528. (DOI: 10.17675/2305-6894-20198-3-3).

26.D. S. Kalyani and S. S. Rao, Effect of various 
factors on corrosion inhibition of carbon steel using a phosphonate-based inhibitor system, Chemical Science and Review Letter, 2014, 2(6), 480-486.

27.V. Sribhurathy and S. Rejendran, Corrosion inhibition by green inhibitor: sodium metavanadate-spirulina system, Chemical Science Review and Letters, 2012, 1(1), 25-29.

28.R. A. Celeste and A. A. Vieira, Localized corrosion inhibition of stainless steel in pure water by oxyanions tungstate and molybdate, Electrochimica Acta, 2004, 49, 2779-2785. (DOI: 10.1016/j.electacta.2004.01.039)

29.F. Eghbali, M. H. Moayed, A. Davoodi and N. Ebrahimi, Critical pitting temperature (CPT) assessment of 2205 duplex stainless steel in 0.1 $\mathrm{M} \mathrm{NaCl}$ at various molybdate concentrations, Corrosion Science, 2011, 53, 513-522. (DOI:10.1016/j.corsci.2010.08.008).

30.M. R. Ali, C. M. Mustafa and M. Habib, Effect of molybdate, nitrite and zinc ions on the corrosion inhibition of mild steel in aqueous chloride media containing cupric ions, Journal of Scientific Research, 2009, 1(1), 82-91.

31.D. B. Pokharel, D. B. Subedi, D. VK and J. Bhattarai, Effects of tungstate and nitrite ions as corrosion inhibitor for $\mathrm{Cr}-10 \mathrm{Zr}-10 \mathrm{~W}$ alloy in $0.5 \mathrm{M} \mathrm{NaCl}$ solution, International Journal of Metallurgy and Alloys, 2019, 5(1), 11-19.

32.D. B. Subedi, D. B. Pokharel and J. Bhattarai, Study of corrosion inhibition mechanism of sputter-deposited W-42Cr-5Ni and Cr-10Zr$10 \mathrm{~W}$ alloys in $0.5 \mathrm{M} \mathrm{NaCl}$ and $1 \mathrm{M} \mathrm{NaOH}$ solutions, International Journal Applied Science and Biotechnology, 2014, 2(4), 537-543. (DOI: 10.3126/ijasbt.v2i4.11531).

33. D. B. Pokharel, D. B. Subedi and J. Bhattarai, Study of the effect of sodium nitrite as green corrosion inhibitor sputter-deposited tungsten-based alloys in $0.5 \mathrm{M} \mathrm{NaCl}$ solution, Bibechana, 2015, 12, 1-12. (DOI: 10.3126/bibechana.v12i0.11670).

34.D. B. Subedi, D. B. Pokharel and J. Bhattarai, Study the corrosion inhibition effect of sodium tungstate for chromium-based ternary alloys in 0.5 $\mathrm{M} \mathrm{NaCl}$ solution, Chemical Science Review and Letters, 2014, 3(12), 1190-1198.

35.D. VK and J. Bhattarai, Effect of sodium tungstate as a green corrosion inhibitor on the passivation behavior of mild steel in aggressive media, International Journal of Applied Science and Biotechnology, 2016, 4(2),183-190. (DOI: 10.3126/ijasbt.v4i2.14885).

36. D. B. Subedi, D. B. Pokharel and J. Bhattarai, Assessment on the effecs of sodium salts of tungstate and nitrite as green inhibitor for the corrosion of $\mathrm{Cr}-5 \mathrm{Ni}-53 \mathrm{~W}$ alloy in $0.5 \mathrm{M} \mathrm{NaCl}$ solution, International Journal of Metallurgy and Alloys, 2020, 6(1), 25-36.

37.H. Justness, Calcium nitrate as corrosion inhibitor for reinforced concrete, In Innovations and Developments in Concrete Materials and Construction (eds. R. K. Dhir, P. C. Hewlett and L. J. Csetenyi), Thomas Telford Ltd. Publishing, London, UK, 2002, 391-402.

38.S. Dong, E. C. La Plante, X. Chen, M. Torabzadegan, M. Balonis, M. Bauchy and G. Sant, Steel corrosion inhibition by calcium nitrate in halide-enriched completion fluid environments, npj Materials Degradation, 2018, 2, 32 (9pp). (Doi: 10.1038/s41529-018-0051-4).

39. H. Nady, M. El-Rabiei and M. Samy, Phosphate and borate ions as inhibiting Aagents for $\mathrm{Cu}-10 \mathrm{Al}-$ $10 \mathrm{Zn}$ corrosion in saline solution, Journal of Bioand Tribo-Corrosion, 2017, 3, 1. (DOI:10.1007/ s40735-016-0065-9).

40. R. Sabzi and R. Arefinia, (2019) Investigation of zinc as a scale and corrosion inhibitor of carbon steel in artificial seawater, Corrosion Science, 2019, 153, 292-300. (https://doi.org/10.1016/j. corsci.2019.03.045).

41. Y. Feng, K.-S. Siow, W.-K. Teo, K.-L. Tan and A.-K. Hsieh, Synergistic effects between sodium tripolyphosphate and zinc sulfate in corrosion inhibition for copper in neutral tap water, Corrosion, 1997, 53(7), 546-555.(DOI: 10.5006/1.3290286).

42. N. R. Phulara and J. Bhattarai, Assessment on corrosion damage of steel-reinforced concrete structures of Kathmandu Valley using corrosion potential mapping method, Journal of the Institute of Engineering, 2019, 15(2), 47-56. (DOI: 10.3126/jie.v15i2.27640).

43. K. P. Dahal, R. K. Karki and J. Bhattarai (2018), Evaluation of corrosivity of soil collected from central part of Kathmandu metropolis (Nepal) to water supply metallic pipes, Asian Journal of Chemistry, 2018, 30(7), 1525-1530. (DOI: 10.14233/ajchem.2018.21211).

44. J. Bhattarai, D. Paudyal and K. P. Dahal, Study on the soil corrosivity towards the buried-metallic 
pipes in Kathmandu and Chitwan valley of Nepal, In: Proceedings of the $17^{\text {th }}$ Asian-Pacific Corrosion Control Conference (1 $7^{\text {th }}$ APCC), 27-30 January 2016, IIT Bombay, Mumbai, India, Paper No. 17039, pp. 12. (https://www.researchgate.net/ publication/293178472).

45.S. K. Regmi, K. P. Dahal and J. Bhattarai, Soil corrosivity to the buried-pipes used in Lalitpur, Kathmandu valley, Nepal, Nepal Journal of Environmental Science, 2015, 3(1), 15-20. (DOI: 10.3126/njes.v3i0.22730).

46.K. P. Dahal, D. KC and J. Bhattarai, Study on the soil corrosivity towards the buried water supply pipelines in Madhyapur Thimi Municipality, Bhaktapur, Bibechana, 2014, 11, 94-102. (DOI: 10.3126/bibechana.v11i0.10387).

47.J. Bhattarai, Study on the corrosive nature of soil towards the buried structures. Scientific World, 2013, 11(11), 43-47. (DOI: 10.3126/ sw.v11i11.8551).

48.P. P. Bhandari, K. P. Dahal and J. Bhattarai, The corrosivity of soil collected from Araniko highway and Sanothimi areas of Bhaktapur, Nepal, Journal of Institute of Science and Technology, 2013, 18(1), 71-77.

49.J. Bhattarai, The electrochemical behavior of carbon steel wires of Nepal in different environments, Journal of Nepal Chemical Society, 2009, 24, 31-38. (DOI: 10.3126/jncs.v24i0.2388).

50. J. Bhattarai, Passivation behavior of steel rod and wires of Nepal in acidic and alkaline solutions, Nepal Journal of Science and Technology, 2008, 9, 157-162. (DOI:10.3126/njst.v9i0.3181).

51.J. Bhattarai, A. Kafle and N. P. Bhattarai, The passivation behavior of carbon steel rods of Nepal in different media, Journal of Nepal Chemical Society, 2007, 22, 34-40. (DOI: 10.3126/jncs. v22i0.520).

52.J. Bhattarai, E. Akiyama, A. Kawashima, K. Asami and K. Hashimoto, The corrosion behavior of sputter-deposited amorphous W-Ti alloys in $6 \mathrm{M} \mathrm{HCl}$ solution, Corrosion Science, 1995, 37, 2071-2086. (DOI: 10.1016/0010-938X(95)001209).

53. M. A. Hegazy, A. S. El-Tabei, A. H. Bedair and M. A. Sadeq, An investigation of three novel nonionic surfactants as corrosion inhibitor for carbon steel in $0.5 \mathrm{M} \mathrm{H}_{2} \mathrm{SO}_{4}$, Corrosion Science, 2012, 54, 219-230.
54. N. A. Negm, M. A. Yousef and S. M. Tawfik, Impact of synthesized and natural compounds in corrosion inhibition of carbon steel and aluminum in acidic media, Recent Patents on Corrosion Science, 2013, 3(1), 1-11.

55. Yu. I. Kuznetsov, N. N. Andreev and S. S. Vesely, Why we reject papers with calculations of inhibitor adsorption based on data on protective effects, International Journal of Corrosion Scale and Inhibitors, 2015, 4(2), 108-109.

56. A. K. Satapathy, G. Gunasekaran, S. C. Sahoo, K. Amit and P. V. Rodrigues, Corrosion inhibition by Justicia gendarussa extract in hydrochloric acid solutions, Corrosion Science, 2009, 51(12), 28482856. (DOI: 10.1016/j.corsci.2009.08.016).

57.J. M. Cases and F. Villieras, Thermodynamic model of ionic and nonionic surfactant adsorption on heterogeneous surfaces, Langmuir, 1992, 8, 1251-1264. (DOI: 10.1021/la00041a005).

58.H. Jha and J. Bhattarai, Corrosion behavior of sputter-deposited $\mathrm{W}-\mathrm{Nb}$ alloys in $\mathrm{NaCl}$ and $\mathrm{NaOH}$ solutions, Journal of Alloy and Compounds, 2008, 456, 474-478. (DOI: 10.1016/j. jallcom.2007.02.100).

59.F.Y. Foo and B.H. Hameed, Insights into the modeling of adsorption isotherm systems, Chemical Engineering Journal, 2010, 156(1), 2-10. (DOI: 10.1016/j.cej.2009.09.013).

60.I. Ahamad, R. Prasad and M. A. Quraishi, Experimental and quantum chemical characterization of the adsorption of some Schiff base compounds of phthaloyl thiocarbohydrazide on the mild steel in acid solutions, Materials Chemistry and Physics, 2010, 124(2-3), 1155-1165. (DOI: 10.1016/j.matchemphys.2010.08.051).

61.K. F. Khaled, Electrochemical investigation and modeling of corrosion inhibition of aluminum in molar nitric acid using some sulfur-containing amines, Corrosion Science, 2010, 52, 2905-2916. (DOI: 10.1016/j.corsci.2010.05.001).

62. Q. B. Zhang and Y. X. Hua, Corrosion inhibition of aluminum in hydrochloric acid solution by alkyl imidazolium ionic liquids, Materials Chemistry and Physics, 2010, 119(1-2), 57-64. (DOI: 10.1016/j.matchemphys.2009.07.035). 